\title{
An Empirical Assessment of Students' Perceptions on Integrated Educational Factors in Islamiyyah Madrasah in North-Central Nigeria
}

\author{
Ahmad Tijani Surajudeen ${ }^{a}$, Muhamad Zahiri Awang Mat ${ }^{\mathrm{b}}$
}

\begin{abstract}
As a response to the problem of dualism, the First World Conference on Muslim Education (Makkah, 1977) proposed the establishment of integrated education in the Muslim world. There is a gap in the literature regarding the implementation of integrated education in the Nigerian context despite an emphasis on the vitality of integrated education paradigm. This study investigated the perceptions of students about integrated education in the context of Islamiyyah madrasah in North-Central Nigeria. A survey questionnaire was used to collect data from 344 respondents in selected Islamiyyah madrasah in the country. The findings indicate that the majority of the respondents perceived that Islamiyyah madrasah balances between Islamic and Western education. The majority of the respondents agreed that they used dialogical pedagogy which allows students to participate during teaching and learning. Moreover, they believed that Islamiyyah madrasah promotes the integration of technology in teaching and learning. In conclusion, it was recommended that the three components of integrated education should be harmonized in order to foster the personality of the learners. Drastic efforts are required to propel integrated education in order to provide opportunity for learners to compete favorably with students of public schools. This necessitates support from all, stakeholders including, government authorities, the National Board of Arabic and Islamic Studies (NBAIS) among others.
\end{abstract}

Keywords: Islamiyyah madrasah, integration, curriculum, pedagogy and technology for teaching and learning

a Department of Curriculum and Instruction, Kuliyyah of Education, International Islamic University Malaysia, E-Mail: sirajudeen_20@yahoo.com b Department of Curriculum and Instruction, Kuliyyah of Education, International Islamic University Malaysia 


\section{Introduction}

Muslim scholars at the First World Conference on Muslim Education held in Makkah in 1977 emphasized the need for integrated education. Subsequently, many Muslim countries including Nigeria began the process of integrating Islamic and western education. The North-Central part of Nigeria is one of the six geo-political zones in the country where integration has been widely practiced through establishment of Qur'anic schools and Islamiyyah madrasah (Philips, 2012). The prime importance of Islamic education and Arabic language on human resource development has been acknowledged in literature (Abubaker, 2004; Oloyede, 2012). The growing interest among Muslim parents to enroll their children into religious schools especially in Islamiyyah madrasah in the North-Central Nigeria has not been adequately studied (Philip, 20112). So far, only a few studies have been conducted to investigate the factors integrated education, especially in contextualizing religious subjects in the North-Central part of Nigeria.

In response to the perceived stagnation of Islamiyyah schools, the federal government and stakeholders in the country have taken a drastic step to address the problem ascribed to the system of Islamiyyah madrasah in the country. Among the proactive steps taken by Nigerian federal government is to integrate the system in order to address the problem of perceived rigidity. Following the Introduction of Universal Basic Education (UBE) in 2010, the Nigerian federal government began the construction of modern schools across many states, equipped with various facilities such as computers. In the year 2010, delegates were sent by the Federal Government of Nigeria (FGN) to visit countries, like Morocco, Egypt, and Sudan, mainly to observe how they integrated western and Islamic education. The report of the delegates was summarized in the Report of the Ministerial Committee on Madrasah (2010). Since then, less attention has been given to investigating the perceptions of the students with respect to the process of integrating Islamic and Western subjects within Islamiyyah madrasah in the country.

Consequently, this study was primarily aimed at assessing the perceptions of the students of Islamiyyah madrasah on the triadic components of integrated education factors (i.e. curriculum, dialogical pedagogy and technology for teaching and learning) in North-Central 
Nigeria. The purpose of examining the factors of integrated education is to address the perceived rigidity, dichotomy and disintegration between revealed and acquired knowledge in the current curriculum championed by the National Board of Arabic and Islamic Studies (NBAIS). The ultimate aim was to standardize the curriculum.

\section{The Concept of Integrated Education}

While the idea of integration of knowledge is not new among Muslim educators, it was the focus of the First World Conference on Muslim Education held in 1977 in Makkah. The idea of Islamization of contemporary knowledge is based on the need for harmonization between revealed knowledge and acquired knowledge (Mohammad Mumtaz Ali, 2010). Adebayo (2005) has interestingly posited that the integration of religious and non-religious subjects can be traced to the 1960s in Nigeria, when was an effort was made to face the challenges of colonialism and western secular schools. Recently, Ahmad and Awang Mat (2013) have argued that the classification and integration of knowledge must be based on the educational model of the Qur'anic perspective. This has been the standpoint of many scholars, intellectuals and academicians in the Nigerian context (Adebayo, 2005). Related to this, the standardization of madrasah curriculum by the National Board of Arabic and Islamic Studies in Nigeria is to unify and include into the curriculum of some non-religious subjects, such as English language, integrated science, citizenship education, etc. (Oloyede, 2012).

The educational thought of the prominent Nigerian scholar, Sheikh Adam Al-Ilory (1917-1992) highlighted the, importance of integrating social studies into the curriculum of madrasah in Nigeria (Olagunju, 1985). This assertion is in line with the educational system of the medieval Islamic civilization whereby knowledge not only served spiritual and intellectual purposes but also served the purposes of social practices, social change and social justice (Chamberlain, 1994). Nonetheless, Islamic education in madrasah today is limited to spiritual and intellectual purposes yet neglects social practices. Moreover, the integration religious and non-religious subjects as embodied in the curriculum design of madrasah or may be meaningless without taking into account the instructional strategy in delivering the content. Consequently, it has been noted that the method used for delivering the contents of the curriculum should be in line with the needs of the 
learners to ensure that their potentials will be activated (Oloyede, 1990). Several methods of teaching, such as lectures, discussions, question and answer sessions, cooperative or collaborative learning have been identified in the approach of Prophet Muhammad (S.A.W.) (Ahmad, 2011). Dialogical pedagogy is vitally important to holistically enhance the personality of the students.

Ahmad (2011) argued that the success of the Muslim scholars in the medieval Islamic civilization could not be separated from their use of the dialogical approach. For instance, Az-Zarnuji and Hasan AlBasri utilized and emphasized the essentiality of dialectical argument specifically for the analysis of a particular text (Ahmad, 2011). AzZarnuji (1947) stressed that discussing, analyzing and understanding a particular text is better than simply memorizing it. However, this does not negate memorization as one of the methods of acquiring knowledge in Islam. It is this method that produced many memorizers of the Qur'an who preserved the contents of the divine message. Despite the vitality of the dialogical pedagogy focuses more on the discussion of abstract ideas through logical reasoning and argumentation, for effective teaching and learning, the use of technology cannot be underrated. Adebayo (2010) notes that while technology and the internet are subject to misuse, vulnerability and susceptibility, the benefit of technology for effective teaching and learning cannot be exaggerated, even as a tool for searching for relevant sources of Islamic education. Indeed, technological facilities such as computers, the internet and favorable environment, have meaningfully contributed to the effective teaching and learning of religious and non-religious subjects.

A good number of recent studies have reiterated the use of technology for effective delivery of Islamic education content in Nigeria (Oloyede, 2004; Oladimeji, 2004; Adebayo, 2010; Ahmad \& Awang Mat, 2011). Hence, recent efforts of the Nigerian government to attain the Millennium Development Goals (MDGs) has compelled the government to address illiteracy and provide essential facilities, including computers and other technological equipment, for madrasahs. Thus an integrated education can be construed to be made of three components, namely, a harmonized curriculum, dialogical pedagogy, and the use of technology for teaching and learning (Figure 1). 


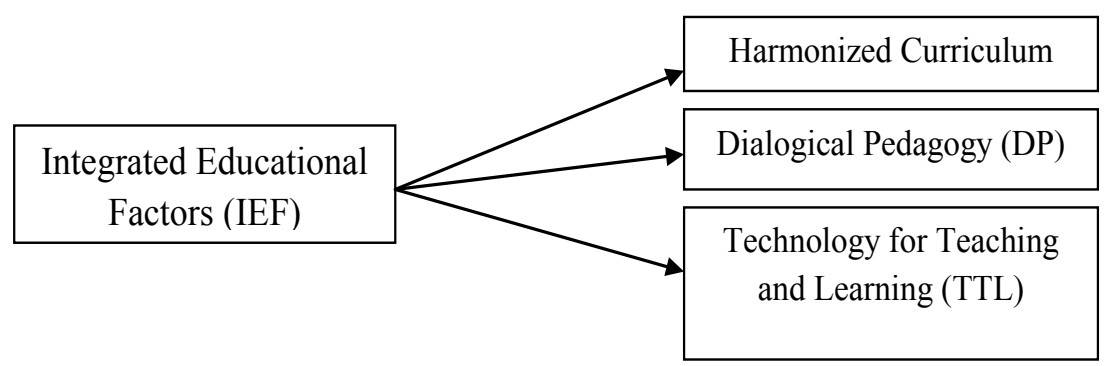

Figure 1: Triadic Components of Integrated Educational Factors (IEF)

(Adapted from: Oloyede, 2004; Oladimeji, 2004; Adebayo, 2010; Oloyede, 2012; Ahmad and Awang Mat, 2013a; Ahmad and Awang Mat, 2013b)

\section{Method}

Survey method was used in this study. The population of the study comprised Islamiyyah madrasah in the entire North-Central geopolitical zone of Nigeria out of which a random sample of volunteers $(\mathrm{n}=344)$ was drawn from senior (Thanawiyyah) and junior (Idadiyyah) secondary students. The majority of the respondents with $246(72 \%)$ were males while females were 98 (29\%). Regarding the respondents' experience in Islamiyyah madrasah, it is explicit that the majority of the respondents with 173 (51\%) have Thānawiyyah experience 157 (46\%) respondents had 'Idaddiyyah experience while only 13 (4\%) have other experiences. Tables 1 and 2 depict the frequencies and percentages of respondents' gender and experience in Islamiyyah madrasah:

Table 1 Frequency and Percentage of Respondents' Gender

\begin{tabular}{ccc}
\hline Gender & Frequency & Percentage \\
\hline Male & 246 & $71.5 \%$ \\
Female & 98 & $28.5 \%$ \\
\hline Total & 344 & $100 \%$ \\
\hline
\end{tabular}

Table 2 Frequency and Percentage of Respondents' experience in Islamiyyah Madrasah 


\begin{tabular}{ccc}
\hline $\begin{array}{c}\text { Level of Islamiyyah Madrasah Expe- } \\
\text { rience }\end{array}$ & Frequency & Percentage \\
\hline Idādiyyah & 157 & $45.6 \%$ \\
Thānawiyyah & 173 & $50.3 \%$ \\
Others & 13 & $3.8 \%$ \\
\hline Total & 344 & $100 \%$ \\
\hline
\end{tabular}

Factors of integrated education as conceptualized in this study are Curriculum, Dialogical Pedagogy (DP) and Technology for Teaching and Learning (TTL). Seven of the items measured the curriculum practice; six measured dialogical pedagogy; while eight items measured the use of technology for teaching and learning among the students of Islamiyyah madrasah, making the total number of items to be 21 . A 5-point Likert Scale was employed namely: $1=$ Strongly Disagree (SD), 2=Disagree (D), 3=Neutral (N), 4=Agree (A) and 5=Strongly Agree (SA). Construct validity was determined by seeking the opinions of the experts, while the reliability of the instrument was determined through Cronbach's Alpha in SPSS version 16.0. The results of the Cronbach's Alpha for each factor were: curriculum $=.812$; dialogical pedagogy $=$ .766; and technology for teaching and learning=.816.

\section{Results}

Below is a summary of the result pertaining to curriculum practices, dialogical and pedagogical practices, and the use of technology for teaching and learning.

\section{Curriculum Practices}

The sample as a whole generally agreed that the curriculum is not promoting the students' ambition to become religious leaders $(M=4.15$, $S D=0.77)$. Only $134(33.5 \%)$ of the respondents disagreed with the statement. Regarding the view that the current practices of curriculum in Islamiyyah madrasah in the country encourage teaching and learning of non-religious subjects such as pure sciences, the sample as a whole agreed $(\mathrm{M}=3.85, S D=0.94)$. Only $28(7 \%)$ of respondents disagreed. In respect to the curriculum practice of Islamiyyah madrasah, the majority of the respondents 201 (50.3\%) strongly believed that they are given or provided with the opportunity to involve in the social development 
of the community $(M=3.74, S D=0.77)$. Very few disagreed with this statement $(\mathrm{n}=7,1.8 \%)$.

Meanwhile, the National Board of Arabic and Islamic Studies (NBAIS) at the Institute of Education Ahmadu Bello University Zaria Nigeria is the body responsible for the coordination and standardization of curriculum of madrasah in the country. The majority of the respondents ( $\mathrm{n}=247,61.7 \%)$ strongly believed that NBAIS has been constantly reviewing the curriculum of Islamiyyah madrasah to provide balanced and holistic personality development of the students $(M=3.92$, $S D=0.74)$.

Pertaining to the content delivery of the curriculum in motivating the students to learn more in Islamiyyah madrasah, the highest number of respondents $(\mathrm{n}=213,53.2 \%)$ strongly agreed with the statement $(M=3.65, S D=0.86)$. Nevertheless, $103(25.8 \%)$ of the respondents maintained neutrality while $28(7.0 \%)$ of the respondents disagreed with the statement.

Moreover, on the students' choice of Islamic education as their future career, 131 (32.8\%) of the respondents showed their agreement in taking Islamic education as their career $(\mathrm{M}=3.26, \mathrm{SD}=0.89)$. The majority of the respondents $151(37.8 \%)$ maintained neutrality while 62 $(15.6 \%)$ disagreed with this statement.

With regard to the evaluation of the curriculum by the madrasah authorities based on the needs of the students, the majority of the respondents 253 (58.8\%) believed that there is constant evaluation of the curriculum toward their educational, intellectual, spiritual and social needs ( $\mathrm{M}=3.90, \mathrm{SD}=0.78)$. Table 3 below illustrates the detailed responses pertaining to the students' level of agreement, disagreement, neutrality and frequency on the curriculum practices in Islamiyyah madrasah in Nigeria. 
Table 3 Students' Responses to the Curriculum Practices in Islamiyyah Madrasah in Nigeria

\begin{tabular}{|c|c|c|c|c|c|c|}
\hline No & Items on Curriculum & 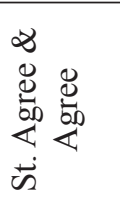 & 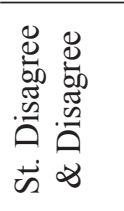 & $\begin{array}{l}\bar{\pi} \\
\stackrel{\Xi}{\Xi} \\
\bar{Z}\end{array}$ & M & $\mathrm{SD}$ \\
\hline 1 & $\begin{array}{l}\text { The content I am current- } \\
\text { ly learning in madrasah } \\
\text { is not only promoting an } \\
\text { ambition to become reli- } \\
\text { gious leaders in the soci- } \\
\text { ety. }\end{array}$ & $\begin{array}{c}33.5 \% \\
(134)\end{array}$ & $\begin{array}{c}33.5 \% \\
(134)\end{array}$ & $\begin{array}{c}19.0 \% \\
(76)\end{array}$ & 4.15 & 0.77 \\
\hline 2 & $\begin{array}{l}\text { The objective of content } \\
\text { I am currently learning } \\
\text { in madrasah encourages } \\
\text { me to learn other subjects } \\
\text { like mathematics, logic, } \\
\text { philosophy and pure sci- } \\
\text { ences. }\end{array}$ & $\begin{array}{c}60.0 \% \\
(240)\end{array}$ & $\begin{array}{l}7.0 \% \\
(28)\end{array}$ & $\begin{array}{c}19.0 \% \\
(76)\end{array}$ & 3.85 & 0.94 \\
\hline 3 & $\begin{array}{l}\text { The current curriculum } \\
\text { of madrasah motivates } \\
\text { me to be involved in the } \\
\text { social development of the } \\
\text { community. }\end{array}$ & $\begin{array}{c}50.3 \% \\
(201)\end{array}$ & $\begin{array}{c}1.8 \% \\
(7)\end{array}$ & $\begin{array}{c}34 \% \\
(136)\end{array}$ & 3.74 & 0.77 \\
\hline 4 & $\begin{array}{l}\text { The National Board of } \\
\text { Arabic and Islamic Stud- } \\
\text { ies (NABAIS) has been } \\
\text { reviewing the current cur- } \\
\text { riculum of madrasah in } \\
\text { order to suit my personal } \\
\text { development. }\end{array}$ & $\begin{array}{c}61.7 \% \\
(247)\end{array}$ & $\begin{array}{c}7.0 \% \\
(28)\end{array}$ & $\begin{array}{c}22.5 \% \\
(90)\end{array}$ & 3.92 & 0.74 \\
\hline 5 & $\begin{array}{l}\text { The current way of deliv- } \\
\text { ering the curriculum by } \\
\text { the teachers encourages } \\
\text { me to learn more. }\end{array}$ & $\begin{array}{c}53.2 \% \\
(213)\end{array}$ & $\begin{array}{c}7.0 \% \\
(28)\end{array}$ & $\begin{array}{c}25.8 \% \\
(103)\end{array}$ & 3.65 & 0.86 \\
\hline 6 & $\begin{array}{l}\text { The current curriculum } \\
\text { encourages me to pursue } \\
\text { Islamic education as my } \\
\text { future career. }\end{array}$ & $\begin{array}{c}32.8 \% \\
(131)\end{array}$ & $\begin{array}{c}15.6 \% \\
(62)\end{array}$ & $\begin{array}{c}37.8 \% \\
(151)\end{array}$ & 3.26 & 0.89 \\
\hline
\end{tabular}




\begin{tabular}{|c|c|c|c|c|c|}
\hline $\begin{array}{l}\text { Madrasah authorities } \\
\text { have been playing essen- } \\
\text { tial role in evaluating the } \\
\text { curriculum towards my } \\
\text { learning needs. }\end{array}$ & $\begin{array}{c}58.8 \\
(253)\end{array}$ & $\begin{array}{l}7.0 \% \\
(28)\end{array}$ & $\begin{array}{c}25.5 \% \\
(102)\end{array}$ & 3.90 & 0.78 \\
\hline Total & $\underline{350.3}$ & $\underline{71.9}$ & $\underline{183.6}$ & $\underline{26.47}$ & $\underline{5.75}$ \\
\hline Total Number of Items & 8 & 8 & 8 & 8 & 8 \\
\hline Mean & 43.8 & 8.98 & 22.92 & 3.30 & 0.71 \\
\hline
\end{tabular}

\section{Dialogical Pedagogical Practices}

Six items were used to measure dialogical pedagogical practices among Islamiyyah madrasah students in Nigeria. The findings from the descriptive statistics showed that there were different views among students regarding the dialogical pedagogical practices in the context of Islamiyyah madrasah in the country. The majority of the respondents $(\mathrm{n}=165,41.4 \%)$ perceived that they like to involve in group discussion and participation in classroom setting in the madrasah while $35(8.8 \%)$ of the respondents disagreed with the statement $(M=3.90, S D=0.78)$.

Pertaining to the analysis of texts that the students are using in the madrasah, a total number of $275(68.7 \%)$ strongly believed that they prefer textual analysis or text-centered than the teachers dominating the instructional strategy in the classroom setting. Only $56(14.0 \%)$ of the respondents disagreed with the statement $(M=4.00, S D=0.63)$.

Regarding the use of dialogical pedagogical practices in the context of Islamiyyah madrasah, $186(56.6 \%)$ of the respondents strongly perceived that their active involvement and participation improves their thinking ability specifically by fostering their understanding of the subject matter being taught in the madrasah $(M=3.57, S D=0.92)$.

Furthermore, the descriptive statistics showed that, a good number of respondents $(\mathrm{n}=220,55.0 \%)$ believed that they are free to express their views; they also strongly perceived that the pedagogical practice being used by the teachers encouraged learners to have the sense of freedom of expression in various religious and non-religious subjects being learnt $(M=3.77, S D=0.72)$. With regard to the students' involvement in argument and their ability to identify their weakness 
Table 4 Students' Responses to the Dialogical Pedagogical Practices in Islamiyyah Madrasah in Nigeria

\begin{tabular}{|c|c|c|c|c|c|c|}
\hline No & $\begin{array}{l}\text { Items on Curriculum } \\
\text { Dialogical Pedagogy }\end{array}$ & 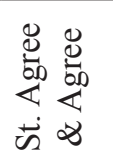 & 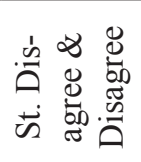 & 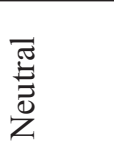 & M & $\mathrm{SD}$ \\
\hline 1 & $\begin{array}{l}\text { I like to be involved ac- } \\
\text { tively in giving my ideas } \\
\text { on issues of discussion in } \\
\text { the classroom setting in } \\
\text { madrasah. }\end{array}$ & $\begin{array}{l}41.4 \% \\
(165)\end{array}$ & $\begin{array}{l}8.8 \% \\
(35)\end{array}$ & $\begin{array}{l}19.0 \% \\
(143)\end{array}$ & 3.58 & 0.89 \\
\hline 2 & $\begin{array}{l}\text { I prefer to be involved in } \\
\text { analyzing the text rather } \\
\text { than teacher dominat- } \\
\text { ing the instruction in } \\
\text { the classroom setting in } \\
\text { madrasah. }\end{array}$ & $\begin{array}{l}68.7 \% \\
(275)\end{array}$ & $\begin{array}{l}14.0 \% \\
(56)\end{array}$ & $\begin{array}{l}17.2 \% \\
(69)\end{array}$ & 4.00 & 0.63 \\
\hline 3 & $\begin{array}{l}\text { My participation during } \\
\text { teaching and learning im- } \\
\text { proves my thinking abil- } \\
\text { ity towards understanding } \\
\text { the subject matter. }\end{array}$ & $\begin{array}{l}56.6 \% \\
(186)\end{array}$ & $\begin{array}{l}1.8 \% \\
(7)\end{array}$ & $\begin{array}{l}30.8 \% \\
(123)\end{array}$ & 3.57 & 0.92 \\
\hline 4 & $\begin{array}{l}\text { I always have the sense of } \\
\text { freedom in expressing my } \\
\text { ideas in all the subjects I } \\
\text { have learnt in madrasah. }\end{array}$ & $\begin{array}{l}55.0 \% \\
(220)\end{array}$ & $\begin{array}{l}7.0 \% \\
(28)\end{array}$ & $\begin{array}{l}29.2 \% \\
(117)\end{array}$ & 3.77 & 0.72 \\
\hline 5 & $\begin{array}{l}\text { I involve myself in argu- } \\
\text { ment in order to over- } \\
\text { come my weakness in } \\
\text { logical reasoning about } \\
\text { religious matters. }\end{array}$ & $\begin{array}{l}39.5 \% \\
(158)\end{array}$ & $\begin{array}{l}5.2 \% \\
(21)\end{array}$ & $\begin{array}{l}41.2 \% \\
(165)\end{array}$ & 3.53 & 0.80 \\
\hline \multirow[t]{4}{*}{6} & $\begin{array}{l}\text { I am involved in con- } \\
\text { structive argument during } \\
\text { discussion in classroom } \\
\text { setting in madrasah. }\end{array}$ & $\begin{array}{l}51.5 \% \\
(160)\end{array}$ & $\begin{array}{l}3.5 \% \\
(14)\end{array}$ & $\begin{array}{l}31.0 \% \\
(124)\end{array}$ & 3.69 & 0.75 \\
\hline & Total & 312.7 & 40.3 & 168.4 & 52.14 & $\underline{4.71}$ \\
\hline & Total Number of Items & 6 & 6 & 6 & 6 & 6 \\
\hline & Mean & 52.11 & 6.71 & 28.06 & 8.69 & 0.78 \\
\hline
\end{tabular}


in logical reasoning about religious issues, 158 (39.5\%) respondents agreed that they involved in argument on religious matters mainly to identify their strengths and weaknesses in logical reasoning $(M=3.53$, $S D=0.80)$. However, Only $21(5.2 \%)$ of the respondents disagreed with this view.

In addition, $160(51.5 \%)$ respondents perceived that they like to partake in constructive argument in the discussion and textual analysis of a particular book they use in the madrasah whereas 124 $(31.0 \%)$ respondents were neutral while only $14(3.5 \%)$ disagreed with the statement $(\mathrm{M}=3.69, \mathrm{SD}=0.75)$. Table 4 illustrates the students' detailed responses pertaining to their level of agreement, disagreement, neutrality and frequencies on the dialogical pedagogical practices in Islamiyyah madrasah in Nigeria.

\section{Technology for Teaching Learning Practices}

Eight items were included in the questionnaire to measure the use of technology for teaching and learning of the students of Islamiyyah madrasah in Nigeria. The sample as a whole strongly agreed that unlike in the past, the present system of Islamiyyah madrasah provides favourable environment for the use of computer facilities. However, $70(17.5 \%)$ respondents disagreed in this regard while $132(33.0 \%)$ maintained neutrality $(\mathrm{M}=3.67, \mathrm{SD}=0.76)$. Further, it is noted that the majority of the respondents (206) (51.1\%) strongly believe that the management of Islamiyyah madrasah are committed and invested in the provision of computer facilities in order to enhance teaching and learning and overall improve the educational system $(M=3.65$, $S D=0.88)$. However, $27(6.8 \%)$ of the respondents disagreed while the total number of $111(27.8 \%)$ were neutral.

Pertaining to the integration of technology for teaching and learning, the majority of the respondents (262) (65.5\%) believed that the use of computer is effective for fostering teaching and learning process ( $M=4.08, S D=0.74)$. Nonetheless, $56(14.0 \%)$ of the respondents disagreed while $82(20.5 \%)$ respondents maintained neutrality. In addition, it is noted that majority of the respondents $(n=219,54.7 \%)$ believed the use of power point and slide presentation is essential to be used for effective teaching in helping the learners understand the lesson. Nevertheless, 90 (22.5\%) respondents disagreed while 91 (22.8\%) were neutral. It is also noted that the majority of respondents $(n=242,60.5 \%)$ 
believed that computer facilities help the students acquire useful skills. On the other hand, 96 (24.0\%) disagreed, however, 61 (16.5\%) of the respondents remained neutral.

In addition, the majority of the respondents $(n=249,62.3 \%)$ believed that the provision of the Internet is useful in searching for necessary information in order to advance their knowledge. But a total number of 95 (23.8) disagreed with this while, 69 (17.3\%) of the respondents were neutral in this regard $(\mathrm{M}=3.92, \mathrm{SD}=0.68)$. It is also asserted that the majority of the respondents $(n=236,59.0 \%)$ believed that provision of a computer lab with several information communication technology (ICT) facilities could be integrated in implementing the curriculum and promoting collaborative or cooperative learning as well as in enhancing skills of the students. However, 96 (23.8\%) of the respondents disagreed while only $69(17.3 \%)$ were neutral $(\mathrm{M}=3.92$, $\mathrm{SD}=0.77)$. Table 5 below illustrates the detailed responses of students' pertaining to their level of agreement, disagreement, neutrality and frequency on the technology for teaching learning practices in Islamiyyah madrasah in Nigeria:

Table 5 Students' Responses to the Teaching Learning Practices in Islamiyyah Madrasah in Nigeria

\begin{tabular}{lcccccc}
\hline No & $\begin{array}{l}\text { Items on Technology } \\
\text { for Teaching Learn- } \\
\text { ing }\end{array}$ & $\begin{array}{c}\text { St Agree } \\
\text { \& Agree }\end{array}$ & $\begin{array}{c}\text { St Dis- } \\
\text { agree \& } \\
\text { Disagree }\end{array}$ & Neutral & $\begin{array}{c}\text { M } \\
(\mu)\end{array}$ & $\begin{array}{c}\text { SD } \\
(\Sigma)\end{array}$ \\
\hline $1 \quad \begin{array}{l}\text { The current madra- } \\
\text { sah system provides } \\
\text { a favourable environ- } \\
\text { ment for the use of } \\
\text { computers. }\end{array}$ & $\begin{array}{c}17.5 \% \\
\text { The madrasah au- }\end{array}$ & $\begin{array}{c}17.5 \% \\
\text { The }\end{array}$ & $33.0 \%$ & 3.67 & 0.76 \\
$\begin{array}{l}\text { thority has invested } \\
\text { in the computer facil- } \\
\text { ity in order to foster } \\
\text { the educational sys- } \\
\text { tem. }\end{array}$ & & $6.8 \%$ & $27.8 \%$ & 3.65 & 0.88 \\
\end{tabular}


3 The current use of computer makes the teaching and learning more effective in $\mathrm{ma}$ drasah.

4 The use of Power Point Presentation in the classroom setting helps me to understand the lesson better.

5 The use of Power Point Presentation in the classroom is useful for my current educational pursuit in madrasah.

6 The access to computers in madrasah motivates me to acquire many skills.

7 Access to the Internet helps me to search for the latest information relevant to my educational progress in madrasah.

8 The computer lab provided in my madrasah enables me to do my activities on time.

\begin{tabular}{|c|c|c|c|c|c|c|}
\hline Total & & 453.8 & $\underline{111.9}$ & 173.9 & 27.25 & 6.21 \\
\hline $\begin{array}{l}\text { Total } \\
\text { Items }\end{array}$ & Number of & 8 & 8 & 8 & 8 & 8 \\
\hline Mean & & 56.72 & 13.98 & 21.74 & 3.40 & 0.77 \\
\hline
\end{tabular}

$65.5 \% \quad 14.0 \% \quad 20.5 \% \quad 4.08 \quad 0.74$

(262) (56) (82)

$\begin{array}{lllll}54.7 \% & 7.0 \% & 22.5 \% & 3.71 & 0.87\end{array}$

(219) (28) (90)

$\begin{array}{lllll}67.2 \% & 17.0 \% & 15.8 \% & 3.96 & 0.69\end{array}$

(269) (68) (63)

$60.5 \% \quad 24.0 \% \quad 16.5 \% \quad 4.01 \quad 0.82$

(242) (96) (61)

$\begin{array}{lllll}62.3 \% & 23.8 \% & 14.0 \% & 3.92 & 0.68\end{array}$

(249) (95) (56)

$\begin{array}{lllll}59.0 \% & 1.8 \% & 23.8 \% & 3.92 & 0.77\end{array}$

(263) (7) (95) 


\section{Discussion}

The main objective of this study was to assess the perceptions of Islamiyyah madrasah students in North-Central Nigeria about integrated educational factors. Three factors of integrated education were examined, namely, curriculum practices, pedagogical practices, and the use of technology for teaching and learning (TTL) in Islamiyyah madrasah in North-Central Nigeria.

It was found that the majority of the learners believed that the curriculum of Islamiyyah madrasah has been improved through the inclusion of non-religious subjects into the curriculum of religious subjects. The findings of this research regarding the integration of religious and non-religious subjects in the curriculum of madrasah agree with those of recent studies that advocated for the necessity of harmonization between revealed and acquired knowledge (Adebayo, 2005; Ahmad \& Awang Mat, 2013). This integration of religious and non-religious subjects in the curriculum of madrasah in Nigeria is contrary to popular assumptions about the rigidity of the curriculum which posits to neglect non-religious subjects.

Recently, the study by Oloyede (2012) has shown that the National Board of Arabic and Islamic Studies (NBAIS) has played a vibrant role towards the standardization of madrasah curriculum by including of some non-religious subjects such as English Language, integrated science, Business Studies, Social Studies and Citizenship Education, among others. Recent studies have demonstrated the significance of social involvement and community service by Muslim students. For instance, the findings of Olagunju (1985) revealed that a renowned Nigerian scholar, Sheikh Adam Al-Ilory (1917-1992) emphasized on the need for social studies and social activities among the Muslim students in the country. Despite the fact that the respondents believed that they are encouraged to partake in community service, their impact is not felt significantly. This may explain why only a few respondents disagreed with the current practices of curriculum of Islamiyyah madrasah due to the fact that there are no pure sciences such as Biology, Physics and Chemistry in the subjects they are currently learning. 
It is essential to reiterate that the majority of the learners perceived that they prefer to engage in discussions and textual analysis of books to enhance their thinking skills, promote the sense of belonging and freedom of expression of ideas in addition to involving in arguments and intellectual discourse to overcome their weakness in logical reasoning as well as learn how to argue constructively about all subjects, whether religious or non-religious. Generally, the students' perceptions about dialogical pedagogy are contradictory to previous studies that criticized the pedagogy of madrasah as being traditional (Ahmad Rufai and Rosnani, 2011). The study by Oloyede (1990) posits that the method of delivering the content of curriculum should be based on the needs of the learners. An inference could be made that dialogical pedagogical practice, as asserted by Oloyede (1990), is an effective pedagogy that could activate the potential of learners' intellectual capacity. Ahmad (2011) showed that many prominent scholars such as Hassan Al-Basrī, Az-Zarnūj̄ì, Al-Ghazālī and Ibn Taymiyyah had been successful in using dialogical pedagogy during the instructional strategy in the medieval Islamic civilization.

Moreover, the literature posits that there are many challenges facing both students and teachers of public secular schools in Nigeria with regard to the use of technological devices for effective teaching and learning. Constant electricity failure is one of the major problems in the country and the accessibility to technological equipment is another major hindrance. Given the existence of these challenges in public schools, the situation in Islamiyyah madrasah must be worse. The Ministerial Report on Madrasah (2010) mentioned that more than ten million children attend madrasah in the country. However, the recent effort of the Nigerian government to accomplish the Millennium Development Goals (MDGs) by 2015 has focused on the provision of essential facilities for madrasah students including equipment such as computers. It is not surprising that the majority of the respondents agreed that technological facilities such as computers and favourable environment have meaningfully contributed to effective teaching and learning of religious and non-religious subjects in some notable Islamiyyah madrasah in the country in general and North-Central in particular. 
Nonetheless, only a few of the respondents disagreed with the use of technology. This could be because there is no provision for the Internet, projectors and computers in their madrasah through which the students can learn audio-visually and enhance their computer literacy skills (CLS). Several studies such as Oloyede (2004) have concluded that the use of technology is instrumental for effective content delivery of Islamic studies. Moreover, the use of the Internet, despite its susceptibility, enables the students to search for relevant materials in order to foster their intellectual potentials and religious practices (Oloyede, 2004; Oladimeji, 2004; Adebayo, 2010).

\section{Conclusion}

This study considered the perceptions of students in respect to the significance of integrated curriculum design that the National Board of Arabic and Islamic Studies (NBAIS) and how to improve the system of Islamiyyah madrasah in Nigeria. In contrast to the popular traditional approach to the pedagogical practices in traditional madrasah system, it was found that dialogical conversation must be activated towards the enhancement of the thinking ability in order to address the dichotomy between the contents of religious sciences and non-religious sciences being taught in Islamiyyah madrasah in the country. In addition, the use of technology for teaching and learning should be emphasized for improving the instructional strategy in the classroom. These findings are a contribution to the discourse on the need for a harmonized curriculum (i.e. unification between revealed and acquired knowledge) as well as the advocacy for the dialogical pedagogy as an effective instructional strategy. It is recommended that, the three components of integrated education assessed in this paper be fostered in order to develop the personality of the learners. Similarly, there is a need for efforts to propel integrated education in order to provide opportunity for learners to compete favourably with students of public schools. Consequently, the stakeholders, government authorities and the National Board of Arabic and Islamic Studies (NBAIS) among others should continue to provide necessary support for the enhancement of Islamiyyah madrasah in the country in order to enable the students to contribute meaningfully to nation building and national aspiration. 


\section{References}

Abubakr, RD. (2004). Interplay of Arabic and Yoruba cultures in south western Nigeria. Iwo: Darul Ilm publisher, Nigeria.

Adebayo, R.I. (2005). Muslim educational reform in south-western Nigeria. in Baffa A.U. et.al (eds) Muslim Educational Reform Activities in Nigeria. Kano; IIIT Nigeria and Faculty of Education, Bayero University.

Adebayo, R.I (2010). The challenges and opportunities of Islamic Studies in the World of modern cyber-technologies: The Nigeria example. Being a paper presented at the International Conference on Knowledge Integration held in PutraJaya, Malaysia.

Adesoji, A. (2011). The Boko Haram uprising and Islamic revivalism in Nigeria. Africa Spectrum, GIGA German Institute of Global and Area Studies, Institute of African Affairs, 45, 2, pp. 95-108.

Adetona, L.M. (2011). The Ilmiyyah schools in the post-independence Lagos. Muslim Educational Quarterly, vol. 24, No. 3 \& 4. The Islamic Academy, Cambridge. $\quad$ U.K., pp.60-68.

Ahmad Rufai, S. and Rosnani, H. (2011). Traditional Islamic education in Asia and Africa: A Comparative Study of Malaysia's Pondok, Indonesia's Pesantren and Nigeria's traditional madrasah. A paper presented at the International conference on Islam in $\quad A f r i c a$ : Intellectual trends, historical sources and research methods. Banquet Hall, ISTAC and Banquet Hall, IIUM Gombak, 19-21 July.

Ahmad, T.S. \& Awang Mat, M.Z.(2013a). Harmonizing educational orientations among madrasah students in Nigeria: Addressing issues in rigidity of Islamic education. Proceedings of the 3rf international conference on Islamic education (ICIED), held at EPF Institute, Kejang, Selangor Malaysia.

Ahmad, T.S. \& Awang Mat, M.Z. (2013b). Classification and integration of knowledge: The qur'anic educational model. Journal of Revelation and Science, Inter-Disciplinary Journal of Intellectual revival, vol. 03, No. 2Pp. 09-22.

Ahmad, T.S. (2011). Discussion method versus students' competence in collaborative learning: The role of Halaqah-study circle- in developing learners'personality traits and critical thinking skills. Germany: Lambert academic publishing.

Ajidagba U. A. (1998). An overview of Islamic education in Nigeria. Journal of Curriculum and Instruction 5, (1 \& 2), Department of Arts and Social Science Education, University of Ilorin, pp. $87-92$. 
Alexander, E. (2006). Understanding Madrasahs. Works for the British Foreign and Commonwealth Office. Published January/February 2006 Issue, Foreign Affairs. Retrieved from http://www.cfr.org/ publication/9461/understanding_madrasahs.html on 29th October, 2012.

Az-Zarnuji B. D. (1947). Ta'lim muta'allim tariq alta'allum. Trans. G.E. von Grunebaum and Theodora M. Abel. New York: King's Crown Press.

Az-Zarnuji, B. D. (2003). Instruction of the student: The method of learning ( $3^{\text {rd }}$ edn). New York: McGraw-Hill.

Bala, A.A. (2009). The contributions of information and communication technology (ICT) to the preservation and dissemination of hadith literature. In Y.O. Imam (editor), Public administration and in information communication technology (ICT) through $t h e$ lenses of Arabic and Islamic Studies. A Publication of the Nigeria Association of Teachers of Arabic and Islamic Studies (NATAIS), Shebotimo Publication, Ijebu- Ode: Nigeria, pp. 134-141.

Boggs, C. (1993). Intellectuals and the crisis of modernity. Albany, NY: Sunny Press.

Boyle, H.N. (2002). The growth of Quranic schooling and the marginalization of Islamic pedagogy: The case of Morocco. Paper presented at the annual meeting of the Comparative and International Education Society, Orlando. FL.

Bradley, J.C. (1999). Islamic versus Western conceptions of education: Reflection on Egypt. International Review of Education, 45:3/4 pp. 339-357.

Chamberlain, M. (1994). Knowledge and social practice in medieval Damascus, 1190-1350. Cambridge: Cambridge University Press.

Conference Book (1977). First World Conference on Muslim Education. King AbdulAzeez University: Kingdom of Saudi Arabia.

Oladimeji, L.F (2009). Utilizing Information and Communication Technology (ICT) in the Teaching of Fiqh (Islamic Jurisprudence) in Akintola, Is-haq et.al (eds) Correlates of Islam; Zaria, Ahmadu Bello University Press.

Olagunju, H.I (1985). Translation with commentaries of Shaykh Adam's Nizam Ta'lim al- Arab was tarikhu fil alam al-Islami.Unpublished Doctoral thesis, University of Ibadan, Ibadan: Nigeria.

Oloyede, I.O. (1990). Utilizing the principles of Ta'lim-Muta'llim for the Islamization of modern techniques of learning. Muslim Education Quarterly, Vol. 7, No.3, pp. 21-36. 
Oloyede, I.O. (2012). Trends, development and challenges of Arabic and Islamic Studies in Nigerian Universities: The contributions of Shaykh Adam Abdullah Al-Ilory in R.D Abubakr (Editor), Shaykh Adam Abdullah Al-Ilory in the Tableau of immortality, vol. II, pp. 45-67.

Oloyede, I.O. (2009). Islamic studies in the World of information and communication technology (ICT): Opportunities and Challenges in Y.O. Imam (editor), Public administration and in information communication technology (ICT) through the lenses of Arabic and Islamic Studies. A Publication of the Nigeria Association of Teachers of Arabic and Islamic Studies (NATAIS), Shebotimo Publication, Ijebu- Ode: Nigeria, pp. 89-101.

Opeloye, M.O. (1994). An assessment of the contributions ilmiyyah schools to Arabic and Islamic learning in the southwestern Nigeria. Muslim Education Quarterly, vol. 11, No. 2, p.31-42.

Rosnani, H. (2007). Intellectualism in higher Islamic traditional studies:

Implications for the curriculum. The American Journal of Islamic Social Sciences 24:3.

Rosnani, H. (2008). Educational dualism in Malaysia: Implications for theory and practice. Kuala Lumpur: Malaysia. 